\title{
A New Strategic Planning Model for Academic Libraries
}

\section{Douglas G. Birdsall and Oliver D. Hensley}

\begin{abstract}
Models provide a framework for visualizing effective action. This paper presents the application of a strategic planning model developed by Oliver Hensley and Martin Schoppmeyer for the Society of Research Administrators. It should have applicability for those who are seeking to establish the future purposes of academic libraries. The example of library development and fund-raising activity is used to illustrate the various stages of strategic planning. The HensleySchoppmeyer model operates on the assumption that people with similar motivations can agree on mutual goals and form beneficial partnerships that will advance $a$ shared interest.
\end{abstract}

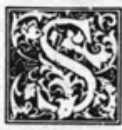

trategic planning for libraries is no longer a new concept. University libraries first recognized its potential through David Kaser's landmark work in 1972 at Cornell, and monographs on the subject now include Donald Riggs' Strategic Planning for Library Managers, M. E. L. Jacob's Strategic Planning: A How-to-Do-It Manual for Librarians, and Strategic Planning in Higher Education: Implementing New Roles for the Academic Library, edited by James F. Williams II. ${ }^{1}$

The journal literature discusses such subjects as the appropriateness of strategic planning for libraries, the incorporation of organizational values into the strategic planning process, the entrepreneurial spirit, implementation and first-year appraisal, and utilization of strategic planning by new directors at ARL libraries. ${ }^{2}$ There are also studies of strategic planning in public libraries, state chapters, a school of library and information science, urban libraries, rural libraries, national libraries, and international libraries. ${ }^{3}$

The Association of Research Libraries issued a SPEC Kit on strategic planning as early as 1984, and the Association of College and Research Libraries has offered a continuing education course ("Principles of Strategic Planning in the Library Environment") and developed a strategic plan for charting the future direction of the Association. ${ }^{4}$

In addition to publications in the literature of librarianship, libraries have access to the rich corpus of management literature on strategic planning, and are likely to be guided and directed by the broader strategic planning done in their institutional settings. George Keller's Academic Strategy: The Management Revolution in American Higher Education reported on the strategic planning undertaken by colleges and universities, which have traditionally been slow to adopt modern management and planning techniques. ${ }^{5}$ Ten years after Keller's study, many academic libraries are important participants in the strategic planning implemented by institutions that must adjust to new economic realities.

Can the library planner in academe find help from yet another source? A monograph published in 1992 by the Society of

Douglas G. Birdsall is Associate Director of Libraries for Information Access and Systems and Oliver D. Hensley is Professor of Education at Texas Tech University, Lubbock, Texas 79409-0002. 
Research Administrators, Strategic Planning for University Research, offers a model for strategic planning which may be the best fit yet for academic libraries. ${ }^{6}$ Strategic planning for university research is a process of establishing the future purposes of a unit by striving for a consensus for developing its research with chief partners and major constituencies. This important collaboration between partners and constituencies has been missing from most libraries' strategic planning. This may be why library strategic plans often gather dust instead of momentum. Library administrators who operate in an increasingly complex information environment should consider carefully a planning process which can help to guide and to coordinate a university's diverse research activity.

The purpose of this article is to present the planning model developed in Strategic Planning for University Research and to illustrate its usefulness for academic libraries. The example of library development and fund-raising activities will be used to show how the model can be adapted by library planners. Fundraising is increasingly important to academic libraries, and the process is best understood when seen from a planning (development) context. $^{7}$

Modeling the strategic planning process allows all who are involved to share a common frame of reference for their planning activities. It also permits planners to monitor progress toward the development of an agreed-upon series of outcomes. The Hensley-Schoppmeyer model used in Strategic Planning for University Research is given in figure 1.

\section{POSITIONING THE ARCHITECTS}

Positioning strategic planning architects for creation of a plan that will enhance funding at a university library is represented in figure 2 .

Positioning the architects is seldom discussed by writers on strategic planning, but the thought given to choosing the best people to do planning is vital for the success of the entire process. The library administration conceives the requisite organizational planning structure and then selects the best planners available. Authority is given to planners in a specific charge. Authority for the planning design can follow traditional hierarchicallines or functionaldivisions, depending on the chief administrator's propensity for managing planning activities.

The current funding crisis in higher education and alternatives to print medium and local ownership are changing the nature of collections and services in research libraries. These issues are of great concern to faculty, campus administrators, students, alumni, and to others who seek the best libraries possible for the institution. The strategic planning involved with generating new funding sources should include all stakeholders, because mutual understanding about problems and obstacles can lead to goals that address the information needs of a diverse university community. The composition of the planning team should include representatives from major impact areas.

Strategic planning operates on the assumption that people with similar motivations can agree on what their mutual purpose should be and can form beneficial partnerships that will advance a shared interest. If long-term success is to be realized, it is critical that awareness, advocacy, and acceptance of needed change involve the library's chief partners and major constituencies. Research libraries have shifted from being supplyto demand-driven operations, and this new alignment necessitates broadly based affiliations. Liaison structures involve the establishment of contacts with a wide spectrum of supporting partners. This includes the positioning of key library administrators on planning and decision-making teams of on- and offcampus organizations. Library administrators look for opportunities to convey their message and secure commitments.

\section{SCANNING THE ENVIRONMENT}

Environmental scans are a standard feature of strategic planning. They identify impact areas, as well as current conditions and future factors that will likely affect the institution or unit. An outline of an environment scan for library development and fund-raising is given in figure 3 . 


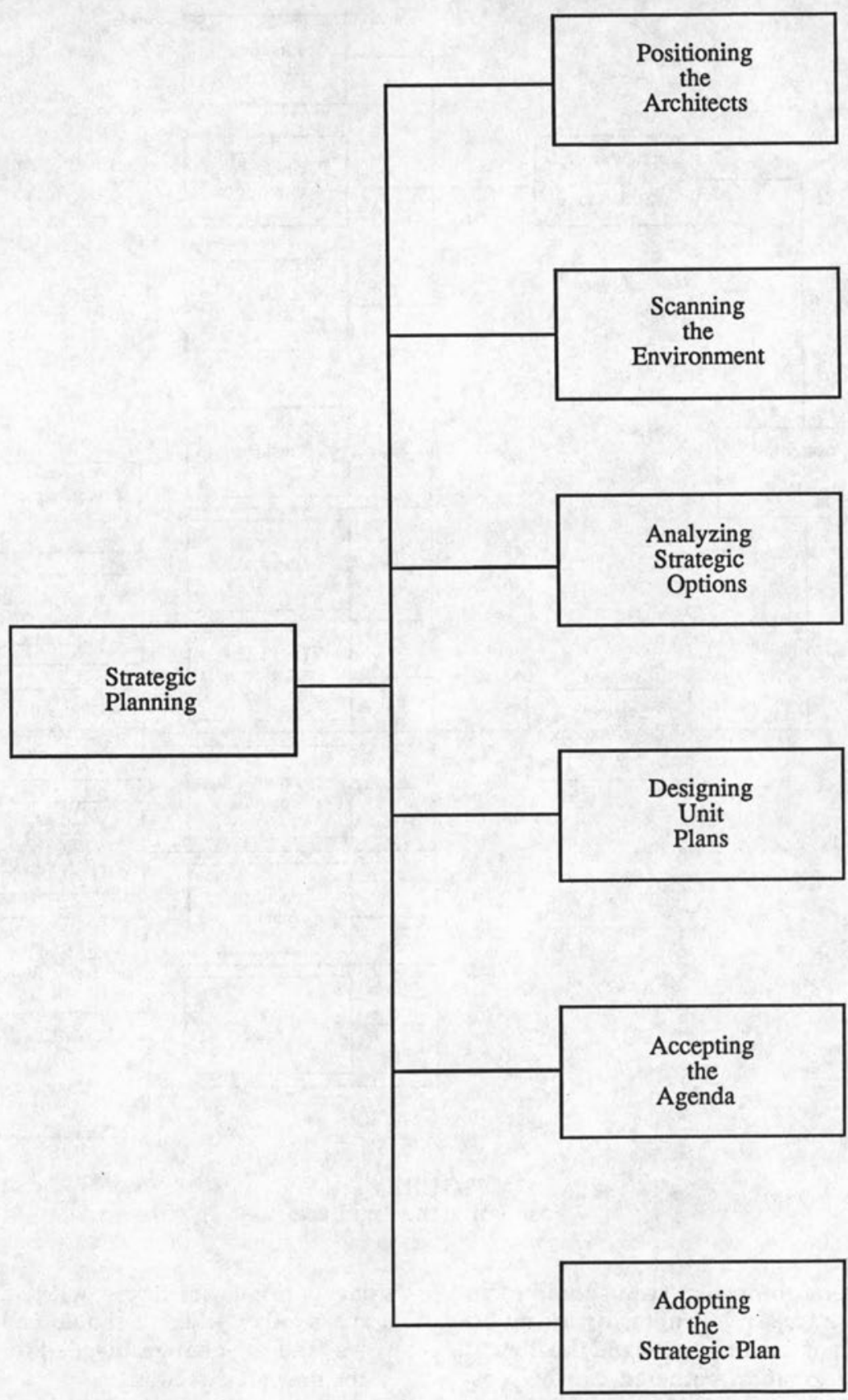

FIGURE 1

Hensley-Schoppmeyer Strategic Planning Model 


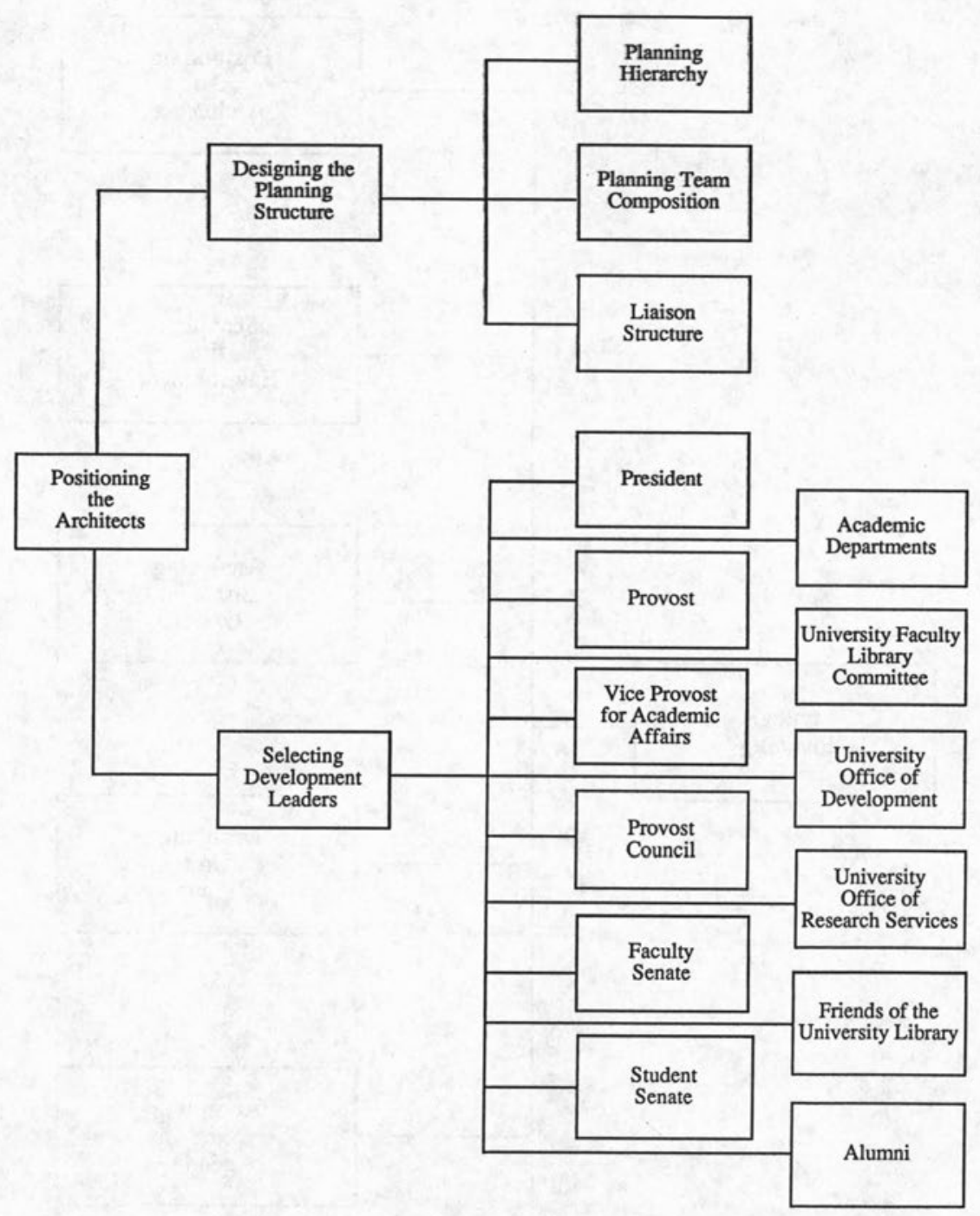

FIGURE 2

Positioning the Architects

The environmental scan should focus on those areas relevant to advancing the mission of the university and the library. The information gathered can help establish a planning framework by identifying the key players and bringing into focus their needs, issues, assumptions, and opportunities. Information is obtained from a number of sources, including librarians, campus administrators, faculty, and students. They are asked where the library is today, where it should be in five years, and the changes needed to move in the desired direction.

\section{ANALYZING STRATEGIC OPTIONS}

In this phase of planning, the advantages and disadvantages of various decision paths are identified and compared. In fund development, scenarios can be 


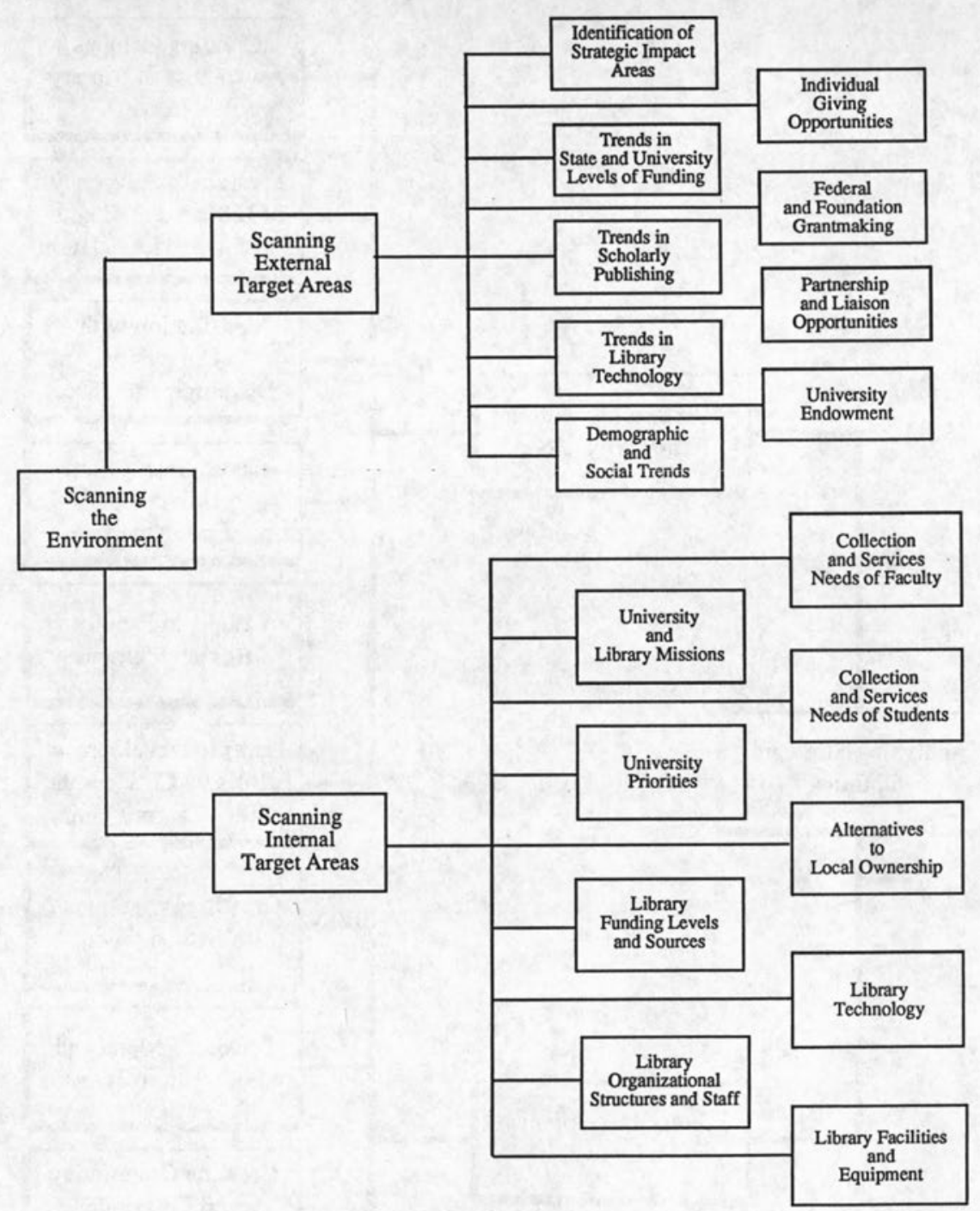

FIGURE 3

Scanning the Environment

cast in various ways. One method is to direct attention to the consequences of various budgeting levels, such as reduction goals, minimal goals, and maximum goals. Other approaches include a status quo or incremental policy, an "access over ownership" orientation, an alarmist option (e.g., buy no books and reduce all building hours), and an analysis and development perspective. Targets exter- nal to the library, such as corporate affiliations, individual giving, and the university endowment, need to be addressed (see figure 4).

However they are presented, an analysis of strategic options should bring together the best scenarios and allow planners to recommend several courses of action at different levels. The scenarios allow all to see what has been 


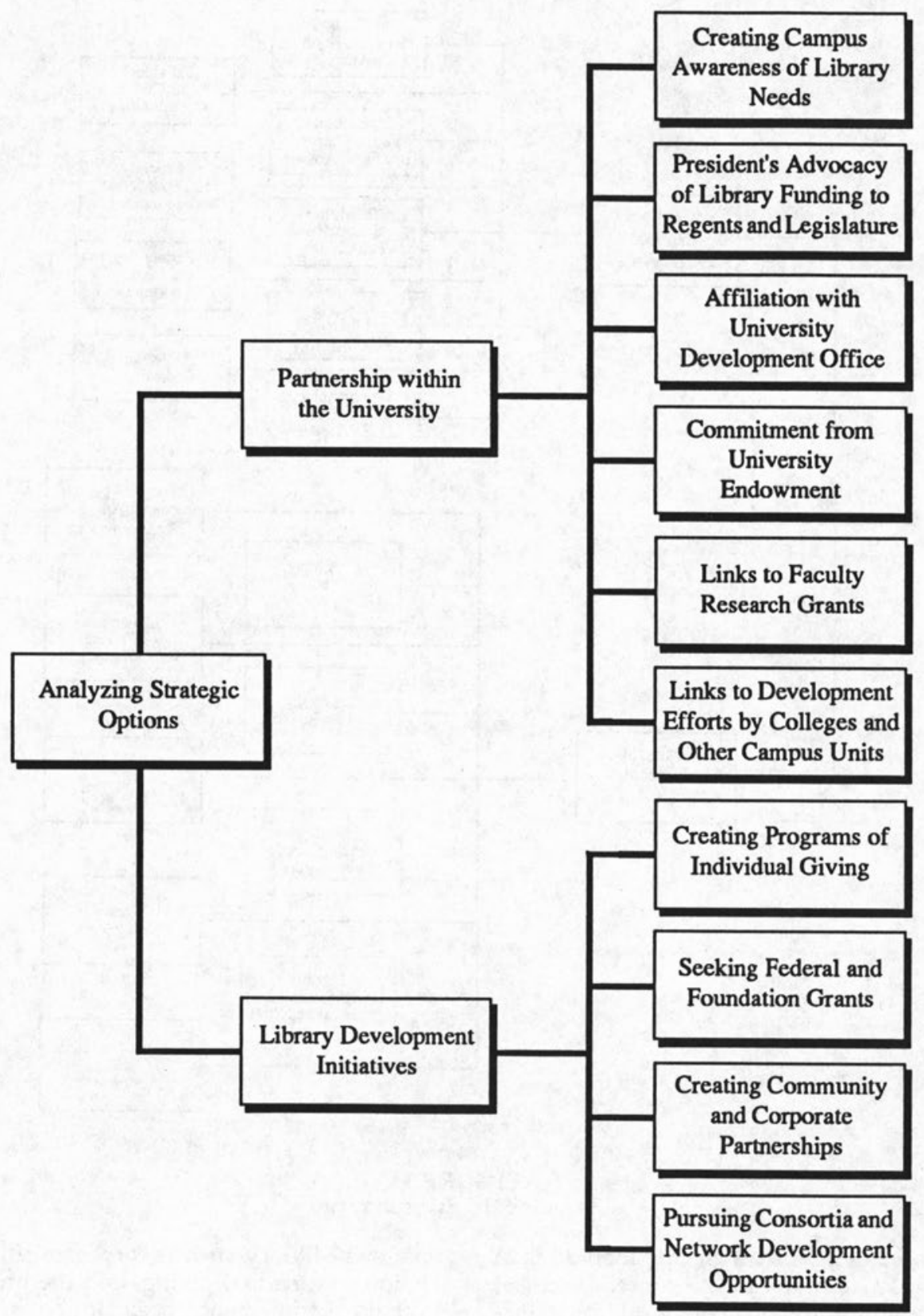

FIGURE 4

Analyzing Strategic Options 
recommended from a particular set of circumstances. Library administrators can then set realistic goals that will guide the library for an extended period of time.

\section{DESIGNING THE PLAN}

At this stage, planners align the goals of the library with the goals of the library's constituencies and the mission of the university. Library administrators match the best ideas of planning participants with the library's limited resources in order to achieve a specified outcome. They must decide on how development efforts will be funded, focused, organized, and staffed. A program for continuous planning and evaluation is created (see figure 5).

Adescription of design elements in the written plan is beyond the scope of this paper; however, many of the characteris-

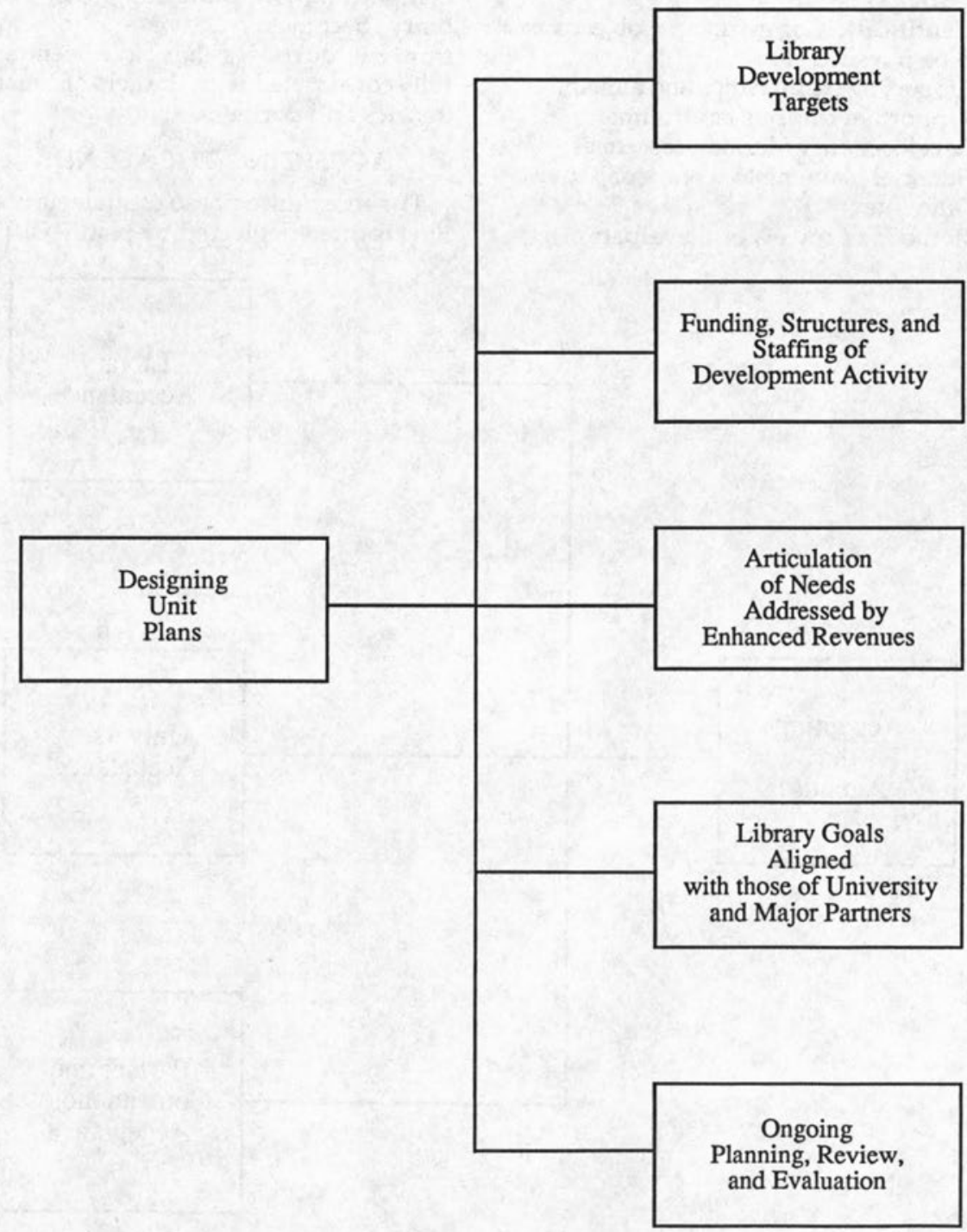

FIGURE 5

Designing Unit Plans 
tics of research unit plans are appropriate for libraries. A planning document should include concise statements on the following:

- Executive summary

- Mission statement

- Analysis of needs or motivating factors

- Value of strategic planning

- Uniqueness of libraries' strengths and weaknesses

- Identification of goals and objectives to be pursued

- Supporting partnerships and affiliations

- Supportive campus environment

- Development of human resources

- Financial planning to achieve objectives

- Time-line

- Methods of review and evaluation
The strategic planning document will provide the basis for the case statement used in fund-raising activities. Of particular importance is the articulation of funding goals. Library needs must be easily understood and marketable to donors. At the same time, these programs and projects have to represent accurately the priorities of the library. If funding is achieved for areas not compatible with planning goals, the library becomes reactive and diverges from the purposes that have been carefully constructed with the help of constituencies and partners.

\section{ACCEPTING THE AGENDA}

The acceptance phase of strategic planning is often neglected by planners. The

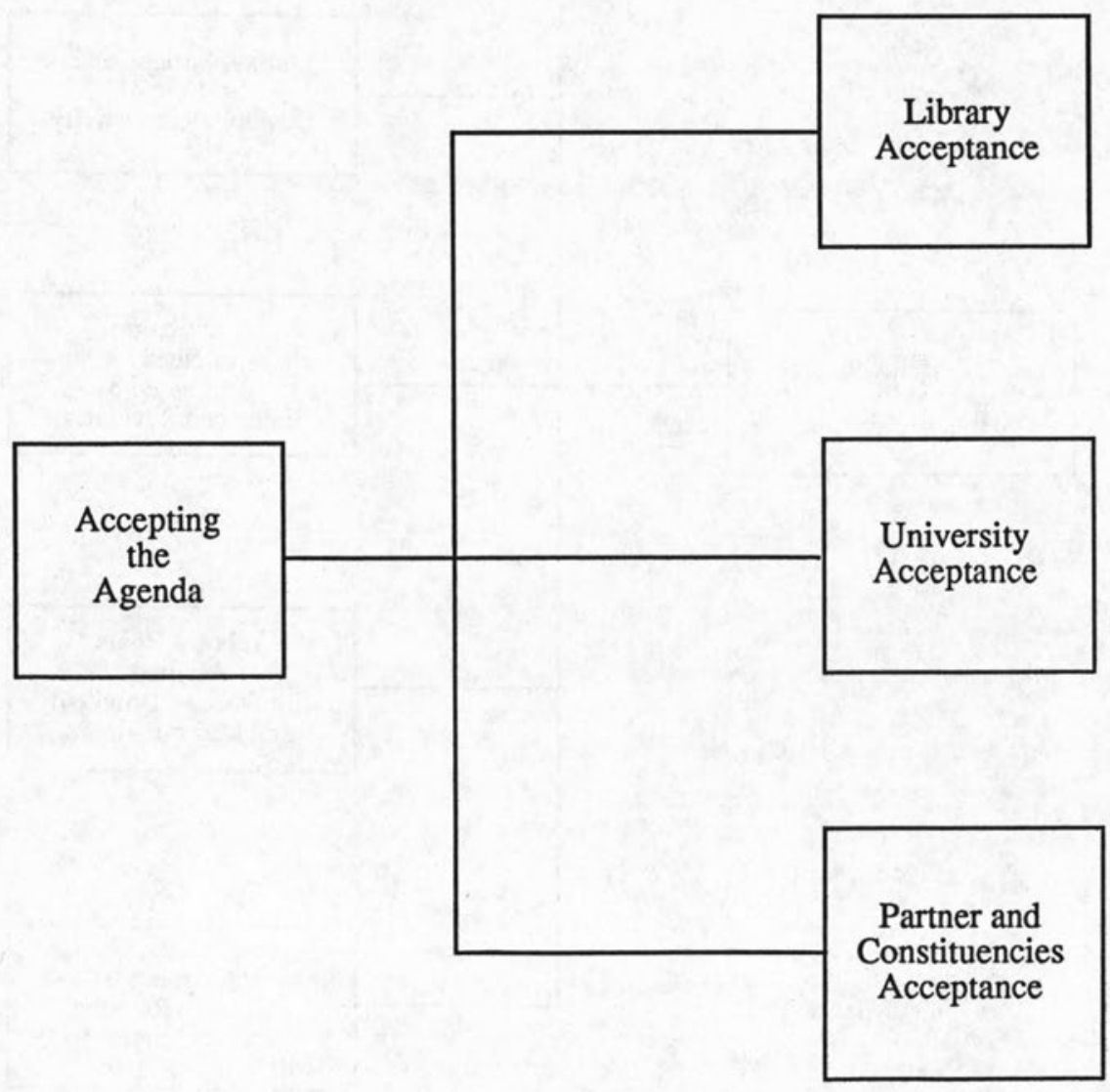

FIGURE 6

Accepting the Agenda 
differences between strategic planning and other types of planning need to be understood. Operational plans are the means of achieving institutional goals according to the budget presented to the unit. Tactical plans determine the specific objectives for achieving those goals. Unless strategic planning is conducted first, both operational and tactical planning are limited to the direction set for the unit by an outside office.

The process of strategic planning reverses in the acceptance phase. Planners stop searching for information and begin to affirm goals, prioritize plans, and seek endorsements from their partners. It is a mistake to think that plan- ning is finished after the environment has been scanned carefully, options have been analyzed, and goals have been set. A design that has only unit support may be a long-range plan for the unit, but it falls short of being strategic planning. Strategic planning requires acceptance of the agenda by partners and constituencies. Acceptance depends on informing stakeholders about what is being planned and how their own goals are advanced by it (see figure 6).

Designing a library plan, even when it involves representatives from impact areas, concerns the articulation of operating activities at one administrative level. Because collegial power is charac-

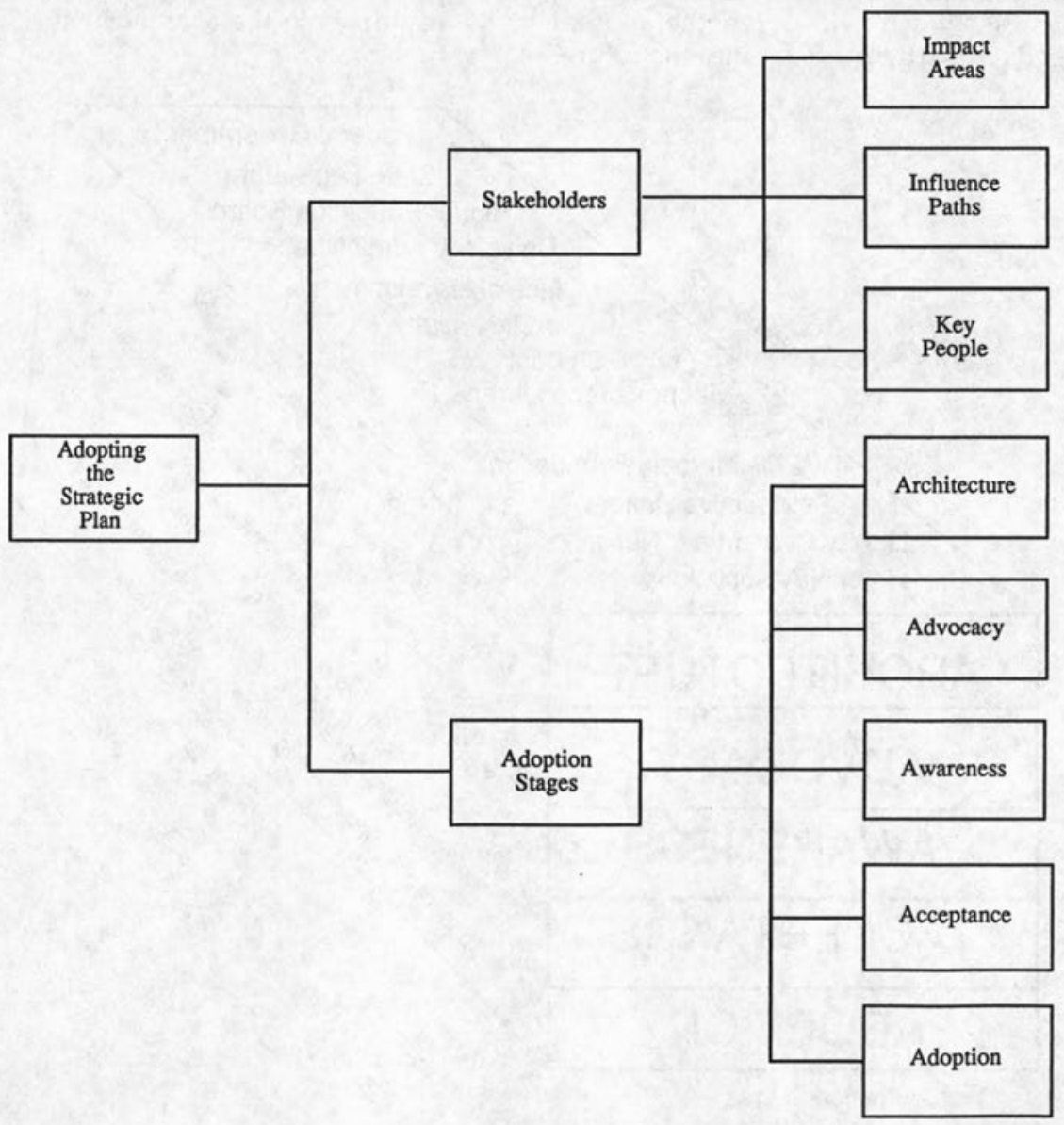

FIGURE 7

Adopting the Strategic Plan 
terized by the sharing of authority and resources, the acceptance phase involves validation from others that the plan is worthwhile and can be promoted as part of the university agenda. Supporting partners, both on and off campus, will have different planning and budgeting mechanisms from those of the soliciting unit, and adjustments will have to be made in order to align the plans, schedules, and budgets of all concerned.

\section{ADOPTING THE PLAN}

Adoption of a strategic plan can be thought to have occurred when principals commit their resources to the advancement of common goals. More important than the amount of enhanced revenue is the establishment of a joint planning process which will serve the mutual needs of participants far into the future.
Adoption, shown in figure 7, occurs in the following stages:

- Architecture-Carefully chosen planners conceive the ideas for change and project that vision to the unit's many constituents.

- Advocacy-Plans are championed that will help to transform the unit's future.

- Awareness-All stakeholders know the benefits and consequences of the plan and feel that the goals are attainable.

- Acceptance-Stakeholders give approval of a schedule for implementation of the plan.

- Adoption-Principals support and adopt both the plan and the strategic planning process. They implement objectives of the plan and contribute their resources to the achievement of mutual goals.

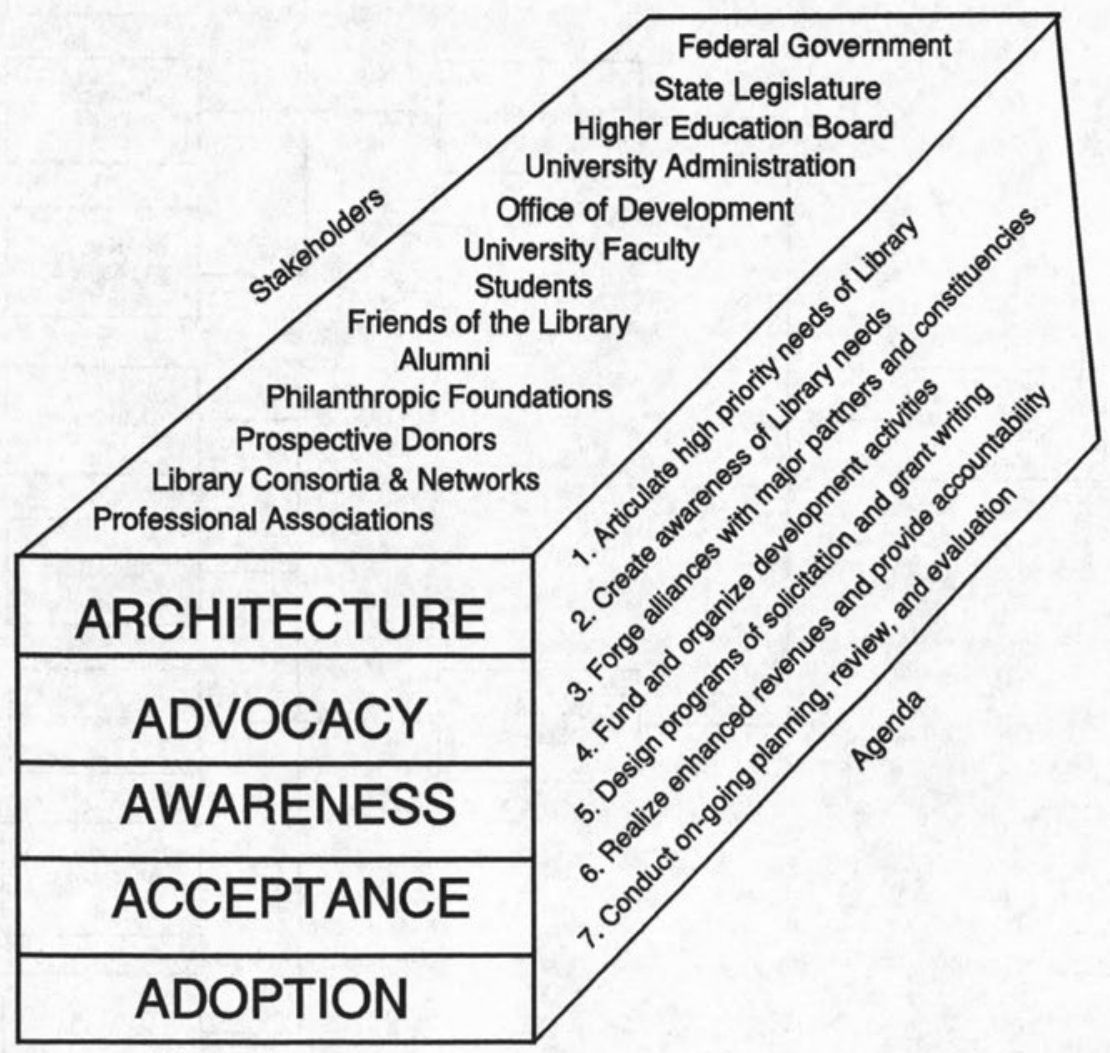

Adoption Stages

FIGURE 8

Change Cube for Library Development and Fund-raising 
Using the example of library development and fund-raising, the change cube model shows the linked facets of agenda, stakeholders, and adoption stages in strategic planning, as shown in figure 8.

\section{CONCLUSION}

Models provide a framework for visualizing effective action. The strategic planning model developed by Hensley
andSchoppmeyoris a design for change in a setting increasingly defined by its array of partnerships. Academic libraries have had long-standing links to the research environment. Now, as they engage in establishing future purposes, librarians may be well served by the planning perspectives being adopted by university research administrators and principal investigators.

\section{REFERENCES AND NOTES}

1. William E. McGrath, Development of a Long-Range Strategic Plan for a University Library: The Cornell Experience; Chronicle of the First-Year's Effort (Ithaca, N.Y.: Cornell University Libraries, 1973). (ERIC Document ED077511); Donald E. Riggs, Strategic Planning for Library Managers (Phoenix, Ariz.: Oryx, 1984); M. E. L. Jacob, Strategic Planning: A How-to-Do-It Manual for Librarians (New York: Neal-Schuman, 1990); James F. Williams II, ed., Strategic Planning in Higher Education: Implementing New Roles for the Academic Library (Binghamton, N.Y.: Haworth, 1991).

2. Ida Vincent, "Strategic Planning and Libraries: Does the Model Fit?" Journal of Library Administration 9 (1988): 35-47; Rick B. Forsman, "Incorporating Organizational Value into the Strategic Planning Process," Journal of Academic Librarianship 16 (July 1990): 150-53; Donald E. Riggs, "Entrepreneurial Spirit in Strategic Planning," Journal of Library Administration 8 (Jan. 1987): 41-52; Bonnie Gratch and E. J. Wood, "Strategic Planning: Implementation and First-Year Appraisal," Journal of Academic Librarianship, 17 (Mar. 1991): 10-15; Meredith Butler and Hiram Davis, "Strategic Planning as a Catalyst for Change in the 1990s," College \& Research Libraries 53 (Sept. 1992): 393-403.

3. Brooke E. Sheldon, "Strategic Planning for Public Library Services in the 21st Century," Journal of Library Administration 11, nos. 1-2, (1989): 199-208; Kathy A. Parsons, "Strategic Planning by the Iowa Chapter of ACRL," College \& Research Libraries News 52 (Jan. 1991): 24-28; Robert M. Hayes, "Strategic Planning for Information Resources in the Research University," RQ 25 (Summer 1986): 427-31, M. E. L. Jacob and D. L. Rings, "Management and Strategic Planning in Urban Libraries," in Trends in Urban Library Management, ed. Mohammed M. Aman and Donald J. Sager (Metuchen, N.J.: Scarecrow, 1989): 17-44; J. L. Grieshop and P. R. Fretz, "Strategic Planning for Rural Libraries: A California Case," Rural Libraries 10, no. 2 (1990): 45-60.Patricia Donlon, "Strategic Planning in National Libraries," IFL A Journal 17, no. 4 (1991): 395-99; Zheng Ting, "A Strategic Plan for Developing University Libraries in China," International Library Review 21 (Oct. 1989): 509-18.

4. Association of College and Research Libraries, Strategic Planning in ARL Libraries (Washington, D.C.:ARL Office of Management Studies, 1984); Julie A. C. Virgo, Principles of Strategic Planning in the Library Environment (Chicago: Association of College and Research Libraries, 1984); Association of College and Research Libraries, ACRL's Strategic Plan (Chicago: Association of College and Research Libraries, 1987).

5. George Keller, Academic Strategy: The Management Revolution in American Higher Education (Baltimore, Md.: Johns Hopkins Univ. Pr., 1983).

6. Oliver D. Hensley, ed., Strategic Planning for University Research, Society of Research Administrators, Monograph no. 4 (Lubbock, Tex.: Texas Tech Univ. Pr., 1992).

7. Mary Bailey Pierce, "Fund-raising/Development Plan," in Raising Money for Academic and Research Libraries, ed. Barbara I. Dewey (New York: Neal-Schuman, 1991$), 1$. 


\section{New from Greenwood Press}

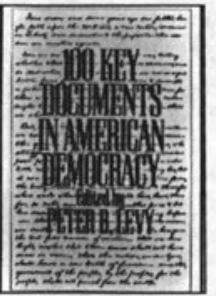

\section{KEY DOCUMENTS IN AMERICAN DEMOCRACY}

Edited by Peter B. Levy

This documentary collection traces the development and meaning of democracy in America from colonial times to the present. Written or spoken by presidents and ex-slaves, political theorists and poets, Supreme Court justices and suffragettes, liberals and conservatives, these documents reflect the diversity of the American experience and the ongoing struggle to achieve the ideals on which the nation was founded.

Greenwood Press. 1993. 536 pages.

0-313-28424-5. \$59.95

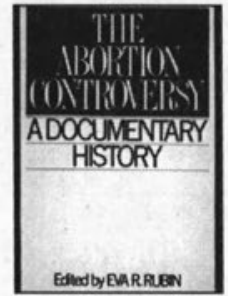

THE ABORTION CONTROVERSY A Documentary History Edited by Eva R. Rubin

Organized by historical period, these 92 documents tell the story of this highly charged issue. The collection emphasizes the political and social aspects of the debate, and many voices and conflicting views resound-in congressional hearings, Supreme Court decisions, government reports, party platforms, position papers, statutes, biographical accounts, and news stories. The book concludes with a chronology of events in the abortion controversy and a list of decisions of the U.S. Supreme Court relating to abortion.

Greenwood Press. 1994. 336 pages.

0-313-28476-8. $\$ 45.00$

\section{BIOGRAPHICAL DIRECTORY OF THE GOVERNORS OF THE UNITED STATES 1988-1994}

\section{By Marie Marmo Mullaney}

This volume, which covers the period 1988-1994, is the latest in a series on colonial, territorial, and state governors from 1607 onward. It is organized alphabetically by state with biographical sketches of the governors appearing in chronological order of their terms of office. The 94 sketches contain information on date and place of birth, education, religion, marriage and family, and an analysis of each governor's professional and political careers. Every entry contains a photograph of the governor and concludes with a bibliography.

Greenwood Press. 1994. 440 pages. 0-313-28312-5. $\$ 75.00$

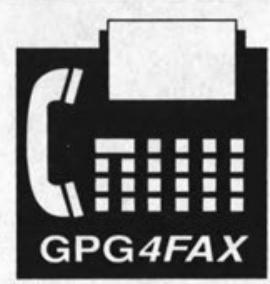

Book information via FAX 24 hours-a-day

\section{1-800-GPG-4FAX (1-800-474-4329)}

If you have a FAX machine and need more information on a GPG title listed here,or any other GPG title, call 1-800-GPG-4FAX (1-800474-4329) on your voice telephone. When instructed, press 1, enter the ISBN for the book you are interested in, then press 1 to receive a FAXed description (complete with table of contents). For a comprehensive list of GPG titles in the area of American History, press 7 for subject and title lists, then enter the subject code 082.

A subject list will be FAXed to you at your request.
88 Post Road West, P.O. Box 5007, Westport, CT 06881-5007

(203) 226-3571 Office Fax (203) 222-1502 